\title{
MULTILEVEL DEMAND \\ FOR SEA TRANSPORTATION. CORRELATION BETWEEN BALTIC DRY INDEX (BDI) AND COASTER SHIPPING PRICES FOR SEA ROUTES BETWEEN BALTIC SEAPORTS AND MEDITERRANEAN SEAPORTS
}

\author{
Svetlana Dimitrakieva, Ognyan Kostadinov, Christiana Atanasova \\ Nikola Vaptsarov Naval Academy (Bulgaria)
}

\begin{abstract}
Baltic Dry Index (BDI) reflects the prices of sea transport performed by Capesize, Panamax, Supramax and Handysize bulk carriers only. The prices of the transport with vessels of smaller tonnage are not considered in the calculation of BDI, therefore principally it should be assumed that BDI does not refer to a tonnage different from the observed. On the other hand, the demand for maritime transport services depends on the state of international trade of goods. Generally, the international market of goods is common for all ship types and tonnages. In the production processes starting from the extraction of raw materials till the sale of finished products to end customers; it can be done by several transport carriages in succession, which provide the intermediate production stages. Transport demand is secondary and depends on international trade, but on the other hand, this demand is multilevel. From an economic point of view, it is important to study the interrelationships between maritime transport providing the intermediate production stages, from the extraction of raw materials till the sale of the final goods.

Keywords: Baltic Dry Index (BDI); freight market; demand, supply; transport services
\end{abstract}

\section{Introduction}

Maritime transport played a major role in global trade and the global economy (Sahin et al. 2018). The lack of provision of the desired transport services at acceptable levels of freight rates is a consequence of a lack of understanding of the needs of the different groups of charterers. These shortages lead to their dissatisfaction, the inability to be detained, and, accordingly, the commercial failure of the company (Plomaritou et al. 2020). 
Thanks to the globalization of the world economy, many multinational companies have been created and developed (Molodchik et al. 2018). These companies used to allocate their production capacity around the world to gain wider access to raw materials, labor, and markets. In most of the studies of international maritime transport, attention is paid only to the transport of raw materials for heavy industry and finished products to the final customers. Little attention is paid to the transport between the different phases of the production process. A closer look at logistics shows competition and innovation, and the complex and dynamic network of ships that moves materials between the various stages of production, of most of the goods traded across the world's oceans. Several maritime transport indices refer to only the two main sectors of maritime shipping - dry bulk and container cargo. These two indices are considered to reflect the economic situation in the dry bulk and container sector only. Understanding the methodology used in these measurements helps us understand the trade and shipping trends, also their importance for overcoming crises. The shipping indices serve the investment process and the commercial management of the fleet.

The BDI published by the Baltic Exchange daily is an aggregated index based on the Baltic Exchange Capesize Index(BCI), the Baltic Exchange Panamax Index (BPI), the Baltic Exchange Supramax Index (BSI), the Baltic Exchange Handysize Index (BHSI). (Angelopoulos) More precisely, the Baltic Dry Index (BDI) tracks prices for the transportation of commodities such as coal, iron ore, steel, cement, and grain around the world.

The information has been available since 1744 when merchants and ship captains began exchanging views during their business. In 1985, the Baltic Exchange presented the BDI as a major sign of the evolution and progress of shipment prices (Apergis et al. 2013). The BDI drives the movement of commodity, currency, and stock markets, as well as the covariance between them (Lin et al. 2019). Different studies use different techniques to make predictions for its course (Zhang et al. 2018).

The index is also linked to the demand of goods, production, construction, and world trade, respectively reflecting not only freight rates for carriage of goods by sea, but also forecasting economic matters (Barrows 2019). The change in the Baltic Dry Index can give investors an idea of global trends in supply and demand. Many believe that a rising or shrinking index is a leading indicator of future economic growth. But it does not apply to coastal ships with a tonnage of 2000 to 8000 DWAT such as those used between seaports of the Baltic Sea and the Mediterranean basin.

\section{Multilevel demand for sea transportation}

Maritime transport participates in the production process of various industries as a link that carries out the transport of raw materials, production materials, 
semi-finished products, and finished products throughout the production process. During the processes of extraction of raw materials, their further processing, also the production and realization as pieces of machinery or finished materials for use in other productions, till the time of the delivery of the finished products to the final customers is carried out by multistage transportation and participation of water transport, reaching up to $2-5$ consecutive carriages by sea. First, large-tonnage ships are used to transport raw materials, then smaller ships transport processed raw materials for mechanical engineering, followed by the transport of machinery or production materials for the light industry, and finally, containers are used to transport finished industrial products to end customers.

All such sea transportations are carried out with the appropriate type of ship, suitable for cargo and transport. In this regard, ships are divided by type of cargo and the route of transport for which they are designed. Demand for raw materials is increased after an economic recession and during economic growth. Then production and investment also increase, and the volume of transport increases accordingly.

On the other hand, during a slowdown in the economy, the demand for raw materials decreases (Bildirici et al. 2015). Maritime transport has a secondary demand, which depends not only on international trade but also follows the process of production of goods. Usually, to take advantage of the economy of scale, raw materials are transported in large quantities, and subsequent production materials and semi-finished products are transported with smaller ships of another type.

Generally, merchant ships are divided into two categories - liquid cargo ships and dry cargo ships.

Transportation of liquid cargo:

- Supertankers with a carrying capacity of more than DWAT 250,000 are used for the transport of crude oil between the seaports from which the goods are exported to the seaports where the oil refineries are located (Dimitrakiev 2019). Petroleum products are different types of fuels, starting with high-octane gasoline, then diesel fuel, and low-quality fuel, such as fuel oil.

- Tankers with a payload of DWAT 20,000 - 30,000 MT are used to transport petroleum products over long distances. DWAT 3,000 MT tankers are used to transport petroleum products over short distances (Dimitrakiev 2020). DWAT 1,500 MT tankers are used to transport petroleum products on Europe's inland waterways, as well as bunkering vessels.

- Other types of dry cargo ships (container vessels and Ro-Ro ships) transport machine oils in barrels or tanks.

The volatility of the dry bulk shipping market has gained widespread attention. Moreover, a significant body of research regarding this instability has been undertaken (Bildirici et al. 2015). 
Transportation of dry cargo:

- Bulk carriers with a carrying capacity between DWAT 40,000 - 400,000 MT are used to transport raw materials for heavy industry, such as iron ore, coal.

- General cargo ships with a carrying capacity between DWAT 10,000 - 20,000 MT are used to transport iron and steel over long distances.

- General cargo vessels with a carrying capacity between DWAT 2,000 - 8,000 MT are used for the transport of high-tech steels.

- General cargo ships and other specialized ships, such as container vessels, also carry small quantities of high-quality steel and semi-finished and finished steel products.

The main raw materials used in industry such as iron ore and oil, from extraction, through post-processing, to finished form, can be transported by more than $3-4$ subsequent shipments by different types of ships.

So, the multi-stage production process requires multi-level transport by different types of ships and tonnage.

Correlation between cargo turnover across the English Channel, coaster shipping freight, Baltic dry index (BDI) and European Union GDP

Table 1. Basic data used for correlation calculations

\begin{tabular}{|c|c|c|c|c|}
\hline 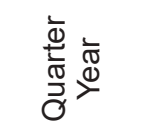 & 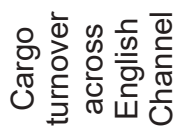 & 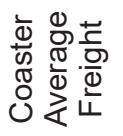 & $\frac{\mathscr{D}}{\frac{\pi}{0}}$ & 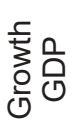 \\
\hline 1st Q'15 & 69839066 & 37.00 & 335 & 0.80 \\
\hline $2^{\text {nd }} Q^{\prime} 15$ & 67918407 & 38.50 & 628 & 0.40 \\
\hline 3rd Q'15 & 62875770 & 36.00 & 965 & 0.30 \\
\hline 4thQ'15 & 68711677 & 36.25 & 613 & 0.50 \\
\hline 1st Q'16 & 65495216 & 35.60 & 361 & 0.50 \\
\hline 2nd Q'16 & 64434973 & 35.50 & 614 & 0.30 \\
\hline
\end{tabular}

Correlations:

Cargo turnover across the Engl.Ch - Coaster Freight $=0.573756951$

Cargo turnover across the Engl.Ch - GDP $=0.79843835$

Coaster Freight - GDP $=0.233184$ 
Analysis:

- Correlation: Cargo turnover across the Engl.Ch - Coaster Freight

The reported correlation from the observations made $\mathrm{R}=0.573756951$ is significant and proves that the cargo turnover is a reliable indicator of price movements in water transport and can be used as a corrective to the basic maritime index for the respective vessels.

- Correlation: Cargo turnover across the Engl.Ch - GDP

The reported correlation from the observations made $\mathrm{R}=0.79843835$ is high and proves that the traffic on the main sea routes of the region, in this case, Western Europe - Mediterranean, can be a reliable source for forecasting.

- Correlation: Coaster Freight - GDP

The reported correlation from the observations made $\mathrm{R}=0.233184$ is weak. Because the measurements are for one regular cargo traffic only, it is quite possible for the error to be bigger than the usual, so further research must be done concerning the relationship between coastal freight and GDP.

Correlation between coaster freights of cargo flow between 2 seaports in Great Britain and 1 unloading seaport in Bulgaria, Baltic dry cargo index (BDI)

Table 2. Basic data used for correlation calculation

\begin{tabular}{|c|c|c|c|c|c|c|c|c|}
\hline data & freight & BDI & data & freight & BDI & data & freight & BDI \\
\hline 20131211 & 39.00 & 2299 & 20151111 & 36.25 & 599 & 20170922 & 35.00 & 1386 \\
\hline 20140219 & 39.75 & 1160 & 20160127 & 35.75 & 337 & 20171130 & 42.00 & 1592 \\
\hline 20140508 & 38.50 & 970 & 20160331 & 35.50 & 414 & 20180219 & 40.50 & 1193 \\
\hline 20140701 & 37.00 & 890 & 20160518 & 35.50 & 579 & 20180413 & 39.75 & 1334 \\
\hline 20140916 & 38.00 & 1124 & 20160707 & 35.50 & 694 & 20180525 & 38.50 & 1012 \\
\hline 20141112 & 39.00 & 1327 & 20161005 & 35.50 & 869 & 20180626 & 41.50 & 1528 \\
\hline 20150209 & 37.00 & 553 & 20161021 & 34.75 & 873 & 20180706 & 38.75 & 1663 \\
\hline 20150421 & 38.50 & 600 & 20161214 & 35.00 & 1003 & 20181002 & 39.50 & 1554 \\
\hline 20150702 & 35.75 & 794 & 20170222 & 35.00 & 806 & & & \\
\hline 20150911 & 36.25 & 885 & 20170502 & 34.50 & 1018 & & & \\
\hline
\end{tabular}

- Correlation between European Freight and BDI: 0.606701.

\section{Analysis:}

In principle, the Baltic Index (BDI) refers to shipments with a different tonnage and navigation area, but short cycles in the economy applicable to all tonnages, so there is an indirect link with European coastal freights. The calculated correlation shows that the indirect correlation between water transport prices for the observed vessels in the calculation of the Baltic Index and the smaller capacity vessels used 
by the subsequent sea services between the Baltic Sea ports and the Mediterranean basin is significant. Larger deviations are also possible, which may be caused by the different supply of tonnage in the observed two sectors, therefore the BDI should not be relied on as a leading index for other types and tonnages of sea-going merchant ships.

\section{Recommendations:}

To obtain more reliable information on the freight market for coastal ships it is necessary to use a set of measurements of variables that can be reported in real-time and values. For the Mediterranean basin, which is important for the economy of Bulgaria and the other countries of the European Union, the following measurements should be made:

1. Object of study Mediterranean - separate measurement of DWAT of ships entering and leaving the Mediterranean, passing through Gibraltar, the Suez Canal, and the Bosporus

2. The measurements should be separated by ship type (tankers, dry cargo ships, etc.) and by usual tonnage groups, for example with DWAT 2000 - 4000 MT, 4000 - 6000 MT, 6000 - 8000 MT.

3. DWAT of all ships entering and leaving the Mediterranean Sea should be measured and calculated with accumulation. The accumulation of tonnage is reasonable to be for 2-3 weeks, according to item 2 .

4. The average speed with an accumulation of 1 week, according to item 2 , should be measured and calculated.

5. A general index between the tonnage and the average speed to be made with the weight of the average speed being less, for example, $10 \%$ weight of the index

6 . The average age of ships to be measured.

The analysis results showed that:

- when the tonnage increases, there is a real increase in demand;

- when the average speed increases, there is an increase in demand.

A strong correlation between these two variables is apparent. (Jurun 2015) Moreover, increasing the average age of the fleet means that there is a reduction of the investments in new construction ships, which may become one of the arguments for investing in a new ship.

\section{Conclusions}

This article examined the correlation between Baltic Dry Index (BDI) and coaster shipping prices for sea routes between Baltic seaports and Mediterranean seaports.

Investment banks, freight forwarders, charterers, ship-owners, disponent owners, and individual investors who make their business choices based on BDI expectations could benefit depending on the exact schedule of the model (Papailias et al. 2017). Our understanding of the Baltic Dry Index helps us to understand 
macroeconomic trends, as well as to make more informed investment decisions. The BDI is a critical component when trying to understand global markets and investment trends around the world.

\section{REFERENCES}

Apergis, N., Payne, J., 2013. New Evidence on the Information and Predictive Content of the Baltic Dry Index. International Journal of Financial Studies (1). ISSN 2227-7072.

Barrows, S., 2019. Are Bulk/Container Shipping Companies Improving Compared to the Baltic Dry Index? Asian Social Science. Published by Canadian Center of Science and Education. 15(12). ISSN 1911-2017.

Bildirici, M., Kayıç̧ı, F., Onat, I., 2015. Baltic Dry Index as a Major Economic Policy Indicator: The relationship with Economic Growth. Procedia - Social and Behavioral Sciences. 210, 416 - 424. doi: 10.1016/j.sbspro.2015.11.389

Dimitrakiev, D., Gunes, E., 2019. Recent Developments and Trends In The Chemical Tanker Market. International Journal of Scientific \& Technology Research 8(12). Available from: http:/www.ijstr.org. ISSN 2277-8616,

Dimitrakiev, D., Gunes, E., 2020. An empirical assessment of the chemical tanker investments. International Journal of Scientific \& Technology Research, 9(02). ISSN 2277-8616

Angelopoulos, J. Time-frequency analysis of the Baltic Dry Index. Maritime Economics \& Logistics 19(2), 211 - 233.

Jurun, E., Ratkovic, N., Moro, F., 2015. The Baltic Dry Index and performance excellence in a crisis environment. Croatian Operational Research Review, CRORR 6, 335 - 346

Lin, A., Chang, H., Hsiao, J., 2019. Does the Baltic Dry Index drive volatility spillovers in the commodities, currency, or stock markets? Transportation Research. Part E(127), 265 - 283.

Molodchik, A., Krutova, A., Elohova, I., Dimitrakiev, D., 2018. Models of platform economy. Proceedings of 11th International Conference Actual economy: local solutions for global challenges ACE-2018, $20-23$. [21.03-24.03.2018].

Papailias, F., Thomakos, D., Liu, J., 2017. The Baltic Dry Index: cyclicalities, forecasting and hedging strategies. Empir Econ. 52, 255 - 282. DOI 10.1007/s00181-016-1081-9

Plomaritou, E., Menelaou, A., 2020. Charter Market Segmentation in Response to Trade's Needs. Journal of Economics, Management and Trade 26(1), 78 - 87, Article no. JEMT.54618. ISSN: 2456-9216 
Sahin, B., Gurgen, S., Unver, B., Altin, I., 2018. Forecasting the Baltic Dry Index by using an artificial neural network approach. Turkish Journal of Electrical Engineering \& Computer Sciences 26, 1673 - 1684.

Zhang, X., Xue, T., Stanley, H., 2018. Comparison of Econometric Models and Artificial Neural Networks Algorithms for the Prediction of Baltic Dry Index, 2169-3536 (c). DOI 10.1109/ACCESS.2018.2884877.

$\triangle$ Svetlana Dimitrakieva https://orcid.org/0000-0001-9639-9957

Nikola Vaptsarov Naval Academy Varna, Bulgaria E-mail: sv.dimitrakieva@naval-acad.bg

$\triangle$ Ognyan Kostadinov

Nikola Vaptsarov Naval Academy Varna, Bulgaria E-mail: o.kostadinov@nvna.eu

Christiana Atanasova https://orcid.org/0000-0003-2102-037X

Nikola Vaptsarov Naval Academy Varna, Bulgaria E-mail:k.atanasova@nvna.eu 